The Cycle of Weathering

By Prof. B. B. Polynov. Translated from the Russian by Alexander Muir. Pp. xii +220 . (London : Thomas Murby and Co., 1937.) 10s. 6d. net.

$\mathrm{T}$ HE science of weathering is fundamental in any study concerned with such a question as why the mineralogical composition of the surface material of the earth is as it is. It is therefore a fundamental science in the study of how geological deposits and soils came to have their present composition. Although this science is so fundamental, it possesses very few established facts. In Nature, weathering is exceedingly slow and very complex, with the consequence that until recently very few methods have been available for examining exactly what chemical processes are taking place. The science of weathering has thus been built up rather more on plausible guess-work than on established fact.

The author of this book, who is one of the leading Russian soil geologists, has not attempted to give a critical presentation of the subject in which the various rival theories are weighed and tested against known experimental data. The book is much more a monograph in which the author sets out to give a general survey of the field of weathering as he himself sees it. He discusses the types of weathering that can take place, and follows up in some detail the cycle of compounds which the commoner chemical elements pass through while in the earth's surface.

In the last chapter the author discusses the effect of topography and of the soil hydrological conditions on the rate at which weathering proceeds. He shows how, in a region having uniform climate and parent material, soils of quite different types would be expected, ranging from the most mature and leached soils on the divides to the most immature soils in the valleys. This effect constitutes what can be called the geomorphological limitation of the theory of the existence of climatic soil groups. This chapter is one of the most suggestive in the book, and the reviewer only regrets that it was not made longer so that more detailed illustrations could be given of the effect of topography. But if it serves as a stimulus for a fuller examination of this effect the book will have been more than justified.

E. W. R.

\section{Scoliodon (the Shark of the Indian Seas)}

By Dr. E. M. Thillayampalam. (Indian Zoological Memoirs on Indian Animal Types, 2.) Second edition, revised and enlarged. Pp. xiv + 126. (Lucknow : Lucknow Publishing House, 1938.) 2.8 rupees.

DROF. BAHL has now presented us with seven memoirs, each dealing with an Indian animal typical of some phylum and taught as a type of the same. The taxonomic position of each is shown, its anatomy and such parts of its physiology as are concerned with its habits in life. The classificatory position in relation to the rest of the Elasmobranchii is carefully considered, aided by forty-nine line illustrations, these leading up to the history of the genus Scoliodon and the consideration of the species.

The anatomical account which follows is interestingly written and excellently illustrated. We are pleased to see modern views on locomotion, and we think the student would be helped by a more 'functional' tone throughout the anatomy. In particular, we should like to see a stronger treatment of the brain and cranial nerves, the broad functions of which apply to all the higher vertebrates.

\section{Physiology of the Central Nervous System and Special} Senses

By Prof. N. J. Vazifdar. Seventh edition, revised and enlarged. Pp. $\mathrm{x}+307+$ vii. (Bombay: Popular Book Depot; London: H. K. Lewis and Co., Ltd., 1938.) 10s. $6 d$. net.

A MEDICAL work which has passed through A seven editions in less than thirty years does not require any further recommendation. It is sufficient to say that the present edition has been well brought up to date and will be found a valuable handbook by the practitioner and student alike.

The text is liberally interspersed with illustrations of the different types of nerve cells, tracts of white matter, transverse sections of the spinal cord, pons and mid-brain, the results of lesions at various parts of the central nervous system, and the structure and function of the special senses.

Fish Passes in Connection with Obstructions in Salmon Rivers :

being the Buckland Lectures for 1937. By T. E. Pryce-Tannatt. Pp. 108. (London: Edward Arnold and Co., 1938.) 3s. 6d. net.

$7 \mathrm{HE}$ subject chosen for the Buckland Lectures for 1937 by Dr. T. E. Pryce-Tannatt was appropriate, for Buckland himself was an inspector of salmon fisheries and was concerned with the question of obstructions in the courses of rivers. This book outlines the laws regarding obstructions, con. siders the obstructions in relation to the habits of the fish, and describes the types of fish passes in existence. The problems concerned with the choice of pass best suited for the varying circumstances are discussed, and thirty-two diagrams and photographs of the different kinds of obstructions and fish passes are given. It maintains the standard of this useful series of publications.

\section{An Inorganic Chemistry}

By Dr. H. G. Denham. Third edition. Pp. viii +694 . (London: Edward Arnold and Co., 1939.) 12s. 6d. net.

THE main alterations in the new edition of Prof.

Denham's book are concerned with the modern view of strong electrolytes and with valency. The last chapter has been extended so as to give a broad outline of the modern theory of valency. The book is of intermediate standard, and particular attention is given to the systematization made possible by the use of the Periodic System.

The possibility of predicting many properties of the compounds of the elements from those of the oxides is also used. The continued popularity of the book may be confidently expected in its new form. 